\title{
Proteome Response of Monascus pilosus during Rice Starch Limitation with Suppression of Monascorubramine Production
}

\author{
Wun-Yuan Lin, ${ }^{\dagger}$ Jui-Yun Chang, ${ }^{\dagger}$ Chin-Hsuan Hish, ${ }^{\dagger}$ And Tzu-Ming Pan $* \star \star$ \\ Department of Food Science, Nutrition and Nutraceutical Biotechnology, Shih Chien University, and \\ Institute of Microbiology and Biochemistry, National Taiwan University, Taipei, Taiwan, Republic of \\ China
}

\begin{abstract}
For centuries, red mold rice has been made by fermentation of cooked rice with Monascus species. However, the influence of different carbon sources on the metabolism of Monascus cells remains unclear. We compared the proteome response of Monascus pilosus to replacement of the rice starch fraction with lactose during cultivation, using two-dimensional gel electrophoresis, matrix-assisted laser desorption-ionization time-of-flight/time-of-flight mass spectrometry, and tandem mass spectrometry to identify the proteins expressed. The results showed that cell growth and monascorubramine pigment formation of $M$. pilosus were sensitive to rice starch limitation during cultivation. A total of 12 proteins were identified with statistically altered expression in the cells cultivated with lactose. These deregulated proteins were involved in glycolysis, TCA cycle, energy generation, protein folding, and peptide biosynthesis. The possible metabolic flux shifts induced by rice starch limitation were discussed. The results suggested that the suppression of monascorubramine formation could be related to the necessary energy-requiring adaptations executed in response to carbon depletion during rice starch limitation.
\end{abstract}

KEYWORDS: Monascus; food pigments; rice; protein extraction; proteomics

\section{INTRODUCTION}

Red mold rice, also known as "red koji” or "angkak", obtained by the fermentation of Monascus species on rice, has been used in East Asia for more than 600 years in the production of wines and other fermented food products. Red koji has long been recognized as a folk medicine for improving food digestion and blood circulation (1). Monascus produces many types of polyketide secondary metabolites with enormous commercial values and many functional properties, including a group of yellow, orange, and red pigments and monacolin $\mathrm{K}$ (also known as lovastatin) (2-5). Currently, Monascus red pigments are important natural food pigments in food applications, such as the coloration of processed products. By using acetyl-CoA as a building block, polyketides are a structurally diverse and complex group of secondary metabolites with a broad range of biological activities (6). To date, most research on Monascus has focused on the optimal growth substrates and conditions in various types of fermentation systems, to enhance secondary metabolite production (7). In Monascus fermentation, carbon utilization affects the production of secondary metabolites (8). Rice starch is considered to be a better carbon source for the

* To whom correspondence should be addressed. Tel: +886-2-33664519. Fax: +886-2-2362-7044. E-mail: tmpan@ntu.edu.tw.

${ }^{\dagger}$ Shih Chien University.

¥ National Taiwan University. production of secondary metabolites, when compared to other carbon sources, such as sucrose, lactose, chitin, and kaoliang starch (9). However, the influence of different carbon sources on the regulation of Monascus gene expression remains unknown, and the metabolic response of Monascus cells to limitation of rice starch during fermentation is an almost completely unexplored field.

On the basis of high-resolution two-dimensional electrophoresis (2-DE) and mass spectrometry, proteomics is a powerful tool for the analysis of hundreds of proteins expressed in a complex mixture at one time $(10)$. The proteome provides a better understanding of the dynamic and overall view of the cell machinery under various conditions. A study of the model system of Bacillus subtilis in stress/starvation using proteomic analysis was used to determine the expression levels of enzymes involved in the glycolysis pathway, pentose phosphate cycle, and citric acid cycle (11). However, as compared to bacteria, plant, and animal analyses, the understanding of the proteome of filamentous fungi is still at a relatively early stage of development (12).

Rice is a staple food consumed throughout the world, particularly in Asian countries. For centuries, red mold rice made from nonwaxy rice has been extensively used for color and flavor in the preparation of traditional Chinese food. The composition of nonwaxy rice includes the major component rice starch (about 80-90\% w/w) and other minor components, such 
as protein and lipid. However, in nonwaxy rice, it remains unclear which component primarily influences the secondary metabolites production in Monascus. Therefore, in this work, we separated nonwaxy rice flour into a destarched fraction and rice-starch fraction (RSF) to investigate which fraction (RSF or destarched fraction) primarily affects the secondary metabolites production in Monascus. In Monascus carbon source utilization, we replaced RSF with lactose as the carbon source in the treatment group to compare the fermentative capacity and induced gene expression between the RSF and a poorly fermentable carbon source, lactose. We found that Monascus pilosus BCRC 31527 culture cultivated in a rice nitrate complex medium with the replacement of RSF with lactose exhibited a complete block in the monascorubramine (MBM) pigment production pathway and repression of cell growth. Because, in the previous study, red-purple pigments were the major produced pigments for $M$. pilosus BCRC 31527 cultivated under the complex medium (13), the polyketide secondary metabolite investigated was focused on MBM red-purple pigments. This investigation addressed the question of how metabolic protein expression of cultured Monascus is affected during the replacement of RSF with lactose in response to suppression of MBM pigment production. The protein expression profiles of the cultured Monascus cells with the RSF-limited medium were characterized using 2-DE, matrix-assisted laser desorption-ionization time-of-flight/time-of-flight mass spectrometry (MALDITOF/TOF MS), and a database search to identify metabolic proteins. The resulting data revealed deregulated expression of proteins involved in glycolysis, TCA cycle, energy generation, protein folding, and peptide biosynthesis during cultivation with lactose. The induction of enzymes involved in ATP generation and reducing equivalent $\mathrm{NAD}(\mathrm{P}) \mathrm{H}$ synthesis in the cultured mycelia of the treated group suggest that the necessary energyrequiring adaptations for early stationary phase survival were executed for the Monascus cells to withstand carbon depletion.

\section{MATERIALS AND METHODS}

Microorganism and Cultivation Conditions. The strain of $M$. pilosus BCRC 31527 used was a high pigment-producing strain (13) and was obtained from the Bioresource Collection and Research Center (BCRC) in Taiwan. Monascus was sporulated and maintained on potato dextrose agar (Merck, Darmstadt, Germany) in stock culture. The control medium for pigment production was a rice sodium nitrate medium consisting of $3 \% \mathrm{w} / \mathrm{v}$ nonwaxy indica rice flour (Oryza sativa, L. indica, containing $86.2 \% \mathrm{w} / \mathrm{w}$ carbohydrate and $7.1 \% \mathrm{w} / \mathrm{w}$ protein, purchased from Sanhaung, a local rice powder producer (Taipei, Taiwan), $0.15 \%$ w/v $\mathrm{NaNO}_{3}, 0.1 \% \mathrm{w} / \mathrm{v} \mathrm{MgSO}_{4} \cdot 7 \mathrm{H}_{2} \mathrm{O}$, and $0.25 \%$ w/v $\mathrm{KH}_{2} \mathrm{PO}_{4}$ as previously described (13). The treatment medium consisted of $0.6 \% \mathrm{w} / \mathrm{v}$ destarched fraction and $2.4 \% \mathrm{w} / \mathrm{v}$ lactose to replace the $3 \% \mathrm{w} / \mathrm{v}$ nonwaxy indica rice flour. Monascus spores, prepared by growth on potato dextrose agar slants for 10 days at $32{ }^{\circ} \mathrm{C}$, were washed with a sterile phosphate buffer $(50 \mathrm{mM}, \mathrm{pH} 7.0)$. In cultivation, a suspension of $10^{8}$ spores was used to inoculate a $1 \mathrm{~L}$ baffled Erlenmeyer flask containing $250 \mathrm{~mL}$ of the control and treated media (before sterilization, the $\mathrm{pH}$ of the media was adjusted to 6.2 with $1 \mathrm{~N} \mathrm{HCl}$ or $1 \mathrm{~N} \mathrm{NaOH}$, respectively), which (containing $250 \mathrm{~mL}$ of medium) were cultivated at $32{ }^{\circ} \mathrm{C}$ for 10 days for submerged fermentation on a rotary shaker at $150 \mathrm{rpm}$ in triplicate.

Reagents and Materials. The 2-DE reagents, including acrylamide solution (25\%), dithiothreitol (DTT), sodium dodecyl sulfate (SDS), trifluoroacetic acid (TFA), urea, iodoacetamide (IAA), thiourea, 3-[(3cholamidopropyl) dimethylammonio]-1-propane sulfonate (CHAPS), Immobiline DryStrips, immobilized pH gradients (IPG) buffer, IPG cover mineral oil, Tris base, and protein assay kit, were purchased from Bio-Rad (Hercules, CA). Sulfanilamide, N-(1-naphthyl) ethylenediamine dihydrochloride, phenylmethanesulfonyl fluoride (PMSF), sorbitol, $\mathrm{N}$-(2-hydroxyethyl) piperazine- $\mathrm{N}^{\prime}$-(2-ethanesulfonic acid) potassium salt
(HEPES-KOH), and $\alpha$-cyano-4-hydroxycinnamic acid (CHCA) were purchased from Sigma (St. Louis, MO). Sypro Ruby stain was purchased from Amersham Biosciences (Piscataway, NJ). Trypsin (modified) was obtained from Promega (Madison, WI). ZipTip C18 microcolumns were purchased from Millipore (Bedford, MA). Other reagents used in this work were of analytical grade and purchased from local suppliers.

Preparation of Destarched Fraction from Nonwaxy Indica Rice Flour. Preparation of the destarched fraction was carried out by an alkaline deproteination method described by Patindol and Wang (14). A $20 \mathrm{~g}$ nonwaxy rice flour sample was soaked in $80 \mathrm{~mL}$ of $0.1 \% \mathrm{NaOH}$ for $8 \mathrm{~h}$ at $8{ }^{\circ} \mathrm{C}$. The soaked sample was then wet-milled in an Osterizer blender (model BPST02-B, San Francisco, CA) for 4 min at speed 6 and centrifuged at $1500 \mathrm{~g}$ for $15 \mathrm{~min}$. The supernatant was collected. The starch residue was then washed with $80 \mathrm{~mL}$ of deionized water twice and centrifuged using the same speed as before, and the supernatants were collected to obtain the destarched fraction. The $\mathrm{pH}$ of the collected supernatant was then adjusted to 6.2 with $0.2 \mathrm{~N} \mathrm{HCl}$ and lyophilized in a vacuum-freeze-dryer (EYELA FDU-540, Tokyo, Japan). The destarched fraction was ground into powder with a mortar.

Measurements of Pigment MBM and Residual Carbon Source Content. Estimation of MBM production was performed as previously described $(5,9)$. After fermentation, the cultured mycelia from a single flask (containing $250 \mathrm{~mL}$ of growth substrate) were filtered, washed with distilled water, and extracted with $80 \mathrm{~mL}$ of $95 \%$ ethanol for $12 \mathrm{~h}$. The filtered solution and extract were made into aliquots, and the absorbance at $495 \mathrm{~nm}$ was measured in a spectrophotometer (Thermo Helios $\alpha$, Waltham, MA). The absorbance in the filtered solution and extract were added to give the total absorbance of MBM production. After fermentation, the residual carbon source content of rice starch or lactose in the supernatant of medium was hydrolyzed into glucose and/ or galactose by $2 \mathrm{~N} \mathrm{HCl}$ solution. For assay of starch contaminants in the destarched fraction, $5 \mathrm{~g}$ of the destarched fraction sample was added with $20 \mathrm{~mL}$ of distilled water, mixed well, and placed in a boiling water bath for $15 \mathrm{~min}$ to gelatinize the starch. After this was cooled to room temperature, $12 \mathrm{~mL}$ of $5 \% \mathrm{w} / \mathrm{v}$ uranyl acetate solution was added to the sample to precipitate proteins. Subsequently centrifuged at $5000 \mathrm{~g}$ for $20 \mathrm{~min}$, the collected supernatant was also hydrolyzed into glucose by $2 \mathrm{~N} \mathrm{HCl}$ solution to determine the starch level in the destarched fraction. Concentrations of glucose were determined using highperformance liquid chromatography (HPLC) and derived from hydrolyzed residual rice starch and lactose in medium and also from hydrolyzed rice starch in the destarched fraction. The HPLC conditions were previously described (13). For dry cell growth mass, the mycelia from a single flask ( $250 \mathrm{~mL}$ of growth substrate) after extraction were lyophilized in a vacuum freeze-dryer (EYELA FDU-540) for 2 days.

Preparation of Protein Extracts. The cultured mycelia were harvested on the fifth day and washed twice with $50 \mathrm{mM}$ phosphate buffer ( $\mathrm{pH} 7.0$ ). After centrifugation of the culture broth at $20000 \mathrm{~g}$ and $4{ }^{\circ} \mathrm{C}$, the cell pellets were stored at $-70{ }^{\circ} \mathrm{C}$ for further analysis. Preparation of cellular proteins for 2-DE was carried out following procedures detailed elsewhere (15). Briefly, after sonication and disruption with a continuous type presser (Constant Systems Ltd., Northants, England), proteins were extracted in a Tris- $\mathrm{HCl}$ buffer. After centrifuging at $40000 \mathrm{~g}$ and $4{ }^{\circ} \mathrm{C}$, the resulting supernatant was mixed with ice-cold trichloroacetic acid and DTT, incubated at $-20{ }^{\circ} \mathrm{C}$ overnight, and washed with ice-cold acetone (containing $0.1 \% \mathrm{w} / \mathrm{v}$ DTT) to obtain the cellular protein pellets. The enriched mitochondrial protein extracts for 2-DE were isolated from the cellular protein pellets following a previously published procedure (12). The $500 \mathrm{mg}$ cellular protein pellet was resuspended in $2 \mathrm{~mL}$ of SHP buffer $(600 \mathrm{mM}$ sorbitol, $20 \mathrm{mM}$ HEPES-KOH, pH 7.4, and $1 \mathrm{mM}$ PMSF) and spun at $600 \mathrm{~g}$ for $10 \mathrm{~min}$ at $4{ }^{\circ} \mathrm{C}$. The supernatant was collected and recentrifuged at $10000 \mathrm{~g}$ for $10 \mathrm{~min}$ at $4{ }^{\circ} \mathrm{C}$ to pellet the enriched mitochondrial fraction. The pellets were washed with $2 \mathrm{~mL}$ of SHP buffer and spun at $10000 \mathrm{~g}$ for $10 \mathrm{~min}$ at $4{ }^{\circ} \mathrm{C}$ to obtain the mitochondrial protein pellets.

Analysis of Proteins by 2-DE. 2-DE protein separation by isoelectric point was performed with an isoelectric focusing system (IPGphor; Amersham Biosciences). The protein pellet was solubilized completely in a sample buffer (7 M urea, $2 \mathrm{M}$ thiourea, $4 \%$ w/v CHAPS, $2 \%$ 
ampholine, and $65 \mathrm{mM}$ DTT, with a trace of bromophenol blue). After 10 min of centrifugation at $18000 \mathrm{~g}$ at $4{ }^{\circ} \mathrm{C}$, the supernatant containing $300 \mu \mathrm{g}$ of cellular proteins was loaded onto the dried IPG strip (18 cm, $\mathrm{pH}$ 3-10 nonlinear; Amersham Biosciences). The protein content was determined by the Bradford method (Protein Assay kit; Bio-Rad). The dried IPG strips were actively rehydrated with loading of protein samples $(300 \mu \mathrm{g} / 350 \mu \mathrm{L})$ at $10 \mathrm{~V}$ for $10 \mathrm{~h}$ at $20^{\circ} \mathrm{C}$ in the ceramic strip holder. Subsequently, isoelectric focusing (IEF) separation and equilibration of gel strips were carried out following previous procedures detailed elsewhere (13). The equilibrated strip was then transferred onto the second-dimension SDS-polyacrylamide gel electrophoresis (PAGE) gel and sealed in place with $0.5 \%$ agarose. SDS-PAGE was performed on $10-18 \%$ gradient polyacrylamide gel at a constant voltage of 10 $\mathrm{mA}$ for $0.25 \mathrm{~h}$ and $45 \mathrm{~mA}$ for $3.5 \mathrm{~h}$ until the dye front reached the bottom of the gel.

In enriched mitochondrial protein 2-DE analysis, the $13 \mathrm{~cm}$ hydrated strip containing $250 \mu \mathrm{g}$ of enriched mitochondrial fraction sample was kept at $20^{\circ} \mathrm{C}$ on an electric field programmed as follows: $100 \mathrm{~V}$ for $1 \mathrm{~h}, 250 \mathrm{~V}$ for $1 \mathrm{~h}, 500 \mathrm{~V}$ for $1 \mathrm{~h}, 1000 \mathrm{~V}$ for $1 \mathrm{~h}, 4000 \mathrm{~V}$ for $1 \mathrm{~h}$, and $8000 \mathrm{~V}$ for $50000 \mathrm{~V} / \mathrm{h}$ for a total of $55970 \mathrm{~V} / \mathrm{h}$. The IPG gel strip was incubated for $15 \mathrm{~min}$ in $50 \mathrm{mM}$ Tris- $\mathrm{HCl}$ buffer (pH 8.8) containing 6 M urea, 30\% v/v glycerol, $2 \% \mathrm{w} / \mathrm{v}$ SDS, and 2\% v/v DTT, followed by equilibration for $15 \mathrm{~min}$ in the same solution containing $2.5 \% \mathrm{w} / \mathrm{v}$ IAA instead of DTT. Separation of proteins by $M_{\mathrm{r}}$ was carried out in a $10 \%$ polyacrylamide gel, $1.5 \mathrm{~mm}$ thick, with a horizontal SDS-PAGE system $(13.5 \mathrm{~cm} \times 13.5 \mathrm{~cm}$, Protean II xi Cell; Bio-Rad) at a constant voltage of $10 \mathrm{~mA}$ for $0.5 \mathrm{~h}$ and $30 \mathrm{~mA}$ for $4 \mathrm{~h}$. For the cellular protein or enriched mitochondrial protein preparation, triplicate gels from each protein extract were analyzed.

Image Analysis and In-Gel Tryptic Digestion. The 2-DE gel proteins were visualized with Sypro Ruby stain. The stained gels were digitized using a computing densitometer (Typhoon 9200 scanner, Amersham Biosciences) and analyzed with PDQuest software (Bio$\mathrm{Rad})$. Protein spots were quantified and characterized with respect to their molecular mass $\left(M_{\mathrm{r}}\right)$ and isoelectric point $(\mathrm{p} I)$ by bilinear interpolation between landmark features on each image previously calibrated with respect to internal 2-DE standards (Bio-Rad). 2-DE gel data were normalized, by dividing each spot quantity by the total quantity of all of the valid spots in the 2-DE gel image, to obtain a normalized spot quantity value. For each matched spot, the mean of the three quantity values from triplicate 2-DE gels was calculated. The differences in protein expression between the control and the treated group were analyzed by Student's $t$ test. The gel spots of interest were manually excised from the gels using biopsy punches. Proteins selected for analysis were in-gel-reduced, alkylated, and digested with trypsin. Briefly, spots were washed twice with water, shrunk for 15 min with $50 \% \mathrm{v} / \mathrm{v}$ acetonitrile $(\mathrm{ACN})$, and dried in a vacuum centrifuge for 30 min. After reduction with $10 \mathrm{mM}$ DTT in $25 \mathrm{mM}$ ammonium bicarbonate for $30 \mathrm{~min}$ at $55^{\circ} \mathrm{C}$, the samples were alkylated with 55 mM IAA in $25 \mathrm{mM}$ ammonium bicarbonate for $20 \mathrm{~min}$ in the dark. Finally, samples were digested with $12.5 \mathrm{ng} / \mathrm{mL}$ sequencing-grade trypsin in $25 \mathrm{mM}$ ammonium bicarbonate $(\mathrm{pH} 8.5)$ for at least $6 \mathrm{~h}$ at $37^{\circ} \mathrm{C}$.

Protein Identification by MALDI-TOF/TOF MS, MS/MS Analysis, and Database Searching. Identification of the peptide sequence of the protein spots was performed using an Applied Biosystems 4700 Proteomics Analyzer mass spectrometer (Applied Biosystems, Framingham, MA) equipped with an Nd:YAG laser (355 nm wavelength, $<500$ ps pulse, and $200 \mathrm{~Hz}$ repetition rate) as previously reported (16). Briefly, the digested tryptic peptide samples were premixed with a $5 \mathrm{mg} / \mathrm{mL}$ matrix solution of CHCA and dissolved in $50 \% \mathrm{ACN}$ with $0.1 \%$ formic acid. MALDI-TOF/TOF-MS detection and MS/MS sequencing of isopeptides were operated in reflector mode. The indicated collision cell pressure was increased from $3.0 \times 10^{-8}$ (no collision gas) to 5.0 $\times 10^{-7}$ Torr. At a resolution above 10000 in MS mode, accurate mass measurement $(<50 \mathrm{ppm})$ of the monoisotopic isopeptide signals was possible. To identify the protein, all MS and MS/MS spectra of tryptic peptides derived from a protein spot were searched against protein sequences from the SwissPort and/or NCBI databases using MASCOT (http://www.matrixscience.com).
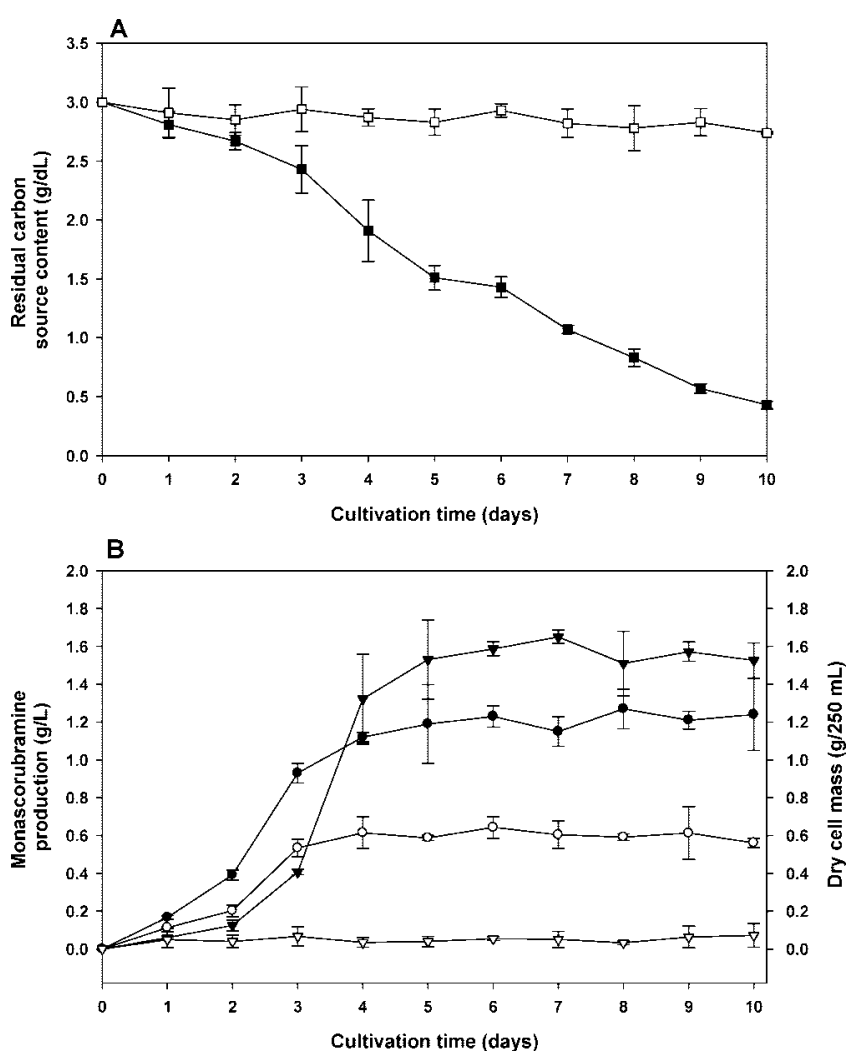

Figure 1. Culture development of M. pilosus BCRC 31527 in the batch type of submerged fermentation on a rotary shaker at $32{ }^{\circ} \mathrm{C}$ and 150 rpm for 10 days. Dry cell mass of the control $(\mathbf{O})$, MBM production of the control $(\boldsymbol{\nabla})$, residual carbon source content in the control medium ( $\boldsymbol{\square})$, dry cell mass of the treated culture $(O)$, MBM production of the treated culture $(\nabla)$, and residual carbon source content in the treated medium ( $\square$ ). The control medium was a rice sodium nitrate medium, and the treated medium was lactose instead of rice starch in the control medium. The data shown were the means \pm SEM from three independent experiments. In part $\mathbf{A}$, the residual carbon source content in the medium was assayed by hydrolyzing rice starch or lactose into monosaccharides and determining monosaccharide levels as residual carbon source content.

\section{RESULTS}

Replacement of Rice Starch with Lactose Inhibited Pigment MBM Production. In traditional food fermentation, nonwaxy rice is the main growth substrate for the fermentation of red mold rice by Monascus. In this work, nonwaxy rice flour was separated into a RSF $(83.2 \% \mathrm{w} / \mathrm{w})$ and a destarched fraction $(14.6 \% \mathrm{w} / \mathrm{w})$ following the previous study (14). Unexpectedly, there was still $1.6 \% \mathrm{w} / \mathrm{w}$ rice starch contaminant observed in the destarched fraction. In the control, the Monascus culture was cultivated with rice nitrate complex medium, which was previously reported as a good pigment-producing medium (17). In the treatment, cultivation of M. pilosus BCRC 31527 with lactose instead of the RSF as the carbon source led to a limitation of RSF in Monascus cultivation. The influence of the metabolism of the cells on protein expression during RSF limitation was investigated using proteomic technology.

In the control, after log phase growth (3 days), M. pilosus BCRC 31527 grew to a dry cell biomass reaching $1.2 \mathrm{~g} / 250$ $\mathrm{mL}$ and its MBM production reached the maximum at midstationary phase (the seventh day) (Figure 1B). Moreover, 85.6\% of rice starch carbon content in the control substrate was consumed during fermentation. By contrast, in the treated group, the cultured mycelia grew poorly with a maximum dry cell growth biomass of only $0.6 \mathrm{~g} / 250 \mathrm{~mL}$ at midstationary phase 


\section{A Cellular proteins}

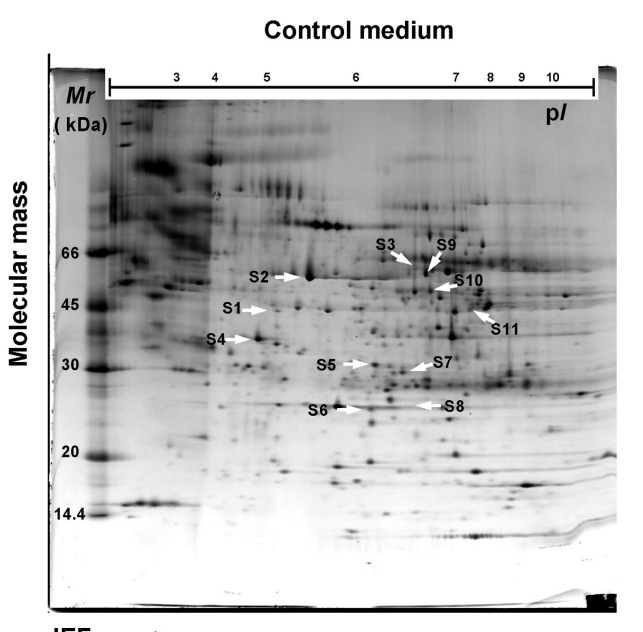

IEF $\longrightarrow$

\section{B Enriched-mitochondrial proteins}

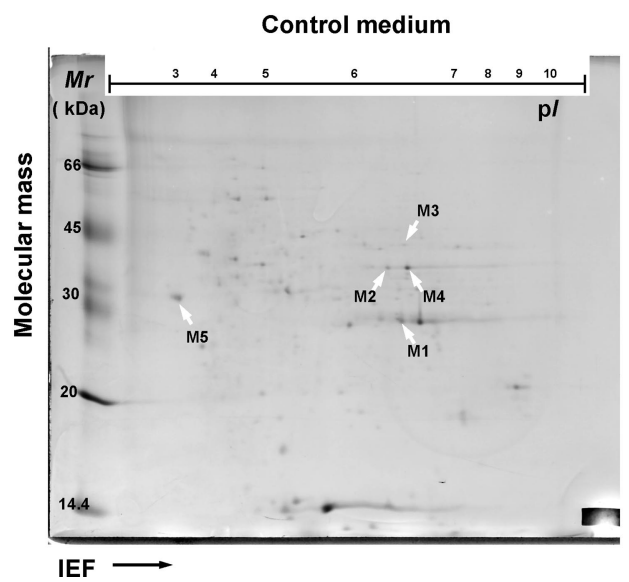

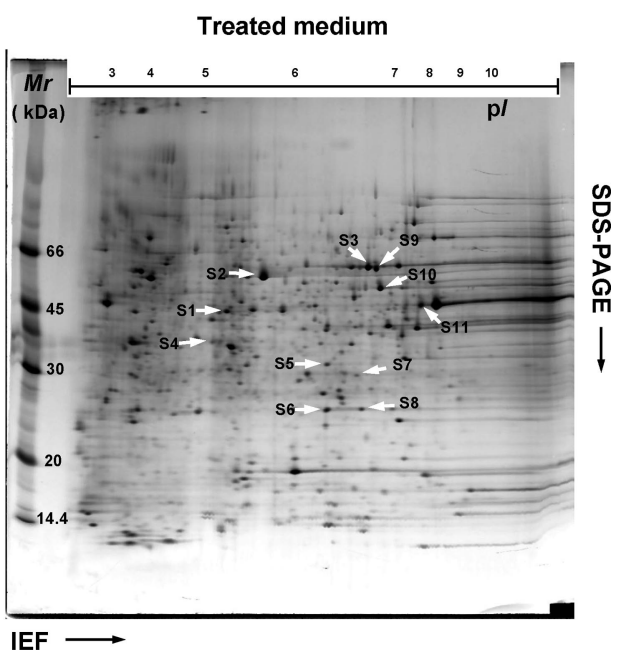

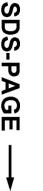

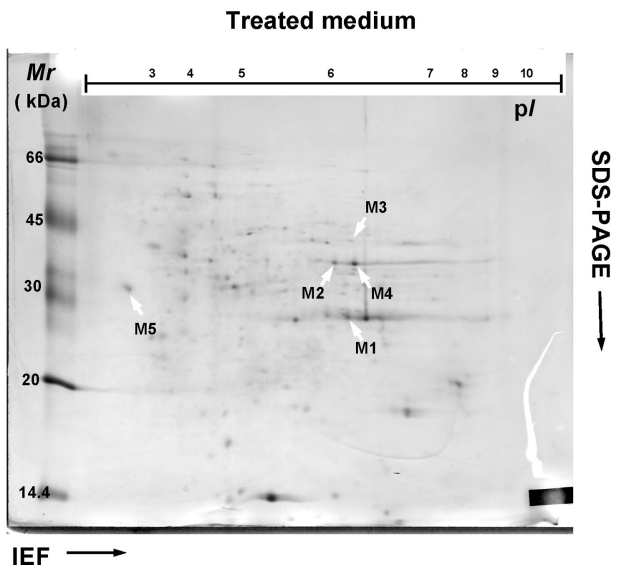

Figure 2. Comparative 2-DE gel analyses of cellular (A) and enriched mitochondrial (B) proteins of $M$. pilosus BCRC 31527 cultivated in the control medium and the treated medium with submerged fermentation at $32{ }^{\circ} \mathrm{C}$ and $150 \mathrm{rpm}$ at the fifth day of cultivation. In part $\mathbf{A}$, the cellular protein ( 300 $\mu \mathrm{g} / 350 \mu \mathrm{L}$ ) extracts were displayed across a $18 \mathrm{~cm}$ IPG strip (pH 3-10) in the first dimension and a 10-18\% gradient SDS-PAGE in the second dimension, stained with Sypro Ruby. In part B, the enriched mitochondrial protein $(250 \mu \mathrm{g} / 350 \mu \mathrm{L})$ extracts were displayed across a $13 \mathrm{~cm}$ IPG strip $(\mathrm{pH} 3-10)$ in the first dimension and a 10\% SDS-PAGE in the second dimension. Isoelectric points $(\mathrm{p} /)$ and molecular masses $\left(M_{\mathrm{r}}\right)$ are marked on horizontal and vertical axes, respectively. Protein spots marked on the maps with arrows and numbers represent 16 identified proteins analyzed with the PDQuest program. Details of the proteins are given in Table 1.

and the MBM production was completely inhibited during fermentation (Figure 1B). Simultaneously, during fermentation, the lactose carbon source in the treated substrate remained almost unused, considered as a nonfermentable carbon source to $M$. pilosus BCRC 31527 cells (Figure 1 A).

Protein Identification by MALDI-TOF/TOF MS and MS/

MS. To characterize the protein expression patterns of M. pilosus BCRC 31527 culture in response to RSF limitation in medium, protein extracts from the Monascus cultured mycelia between the treated and the control samples were compared by 2-DE analysis. Because the cultured mycelia at the fifth day of the stationary-phase cultivation exhibited an obvious treatmentinduced difference in MBM production between the treated and the control samples (Figure $\mathbf{1}$ B), it was at this point that we harvested and extracted proteins for 2-DE analysis. Proteins were resolved using a $18 \mathrm{~cm} \times 18 \mathrm{~cm} 2$-DE gel for cellular proteins and a $13 \mathrm{~cm} \times 13 \mathrm{~cm} \mathrm{2-DE} \mathrm{gel} \mathrm{for} \mathrm{the} \mathrm{enriched} \mathrm{mitochondrial}$ protein preparation. Preliminary 2-DE gel analysis of proteins using IPG strips across the $\mathrm{pH}$ range from 3 to 10 or from 4 to 7 demonstrated that most cellular proteins and enriched mitochondrial proteins were separated in the $\mathrm{pH} 3-10$ range. To ensure that identical proteins in different gels were recognized as identical in the image registration, a consensus gel image combining the information content of all individual images was generated by registration of several gel images. 2-DE gel maps of $M$. pilosus BCRC 31527 cultured mycelia from the cellular and enriched mitochondrial protein preparations are illustrated in Figure 2, visualized with Sypro Ruby staining.

By using the PDQuest program (Bio-Rad), comparison of the spot areas and densities of the protein spots between the treated and the control samples allowed the selection of 65 protein spots of interest, most showing different intensities in expression levels. The 65 protein spots were cut and analyzed by a combination of MALDI-TOF/TOF MS and MS/MS. Using cross-species identification (CSI) to increase the size of the protein database $(18,19)$, these identified proteins were matched to known proteins from related fungus species, such as Saccharomyces cerevisiae and Aspergillus niger, and to lesser related bacterium species, such as Escherichia coli. The identified proteins are highlighted and numbered on the protein reference map shown in Figure 2. Two of the identified proteins, cytosolic adenylate kinase (AK) and aspartyl-tRNA synthetase 
Table 1. List of Identified Protein Spots of 2-DE Gel Analyses of Cellular Proteins and Enriched Mitochondrial Proteins of M. pilosus BCRC 31527 Cultivated in the Control Medium and the Treated Medium

\begin{tabular}{|c|c|c|c|c|c|c|c|c|c|}
\hline $\begin{array}{l}\text { spot } \\
\text { name }\end{array}$ & $\begin{array}{l}\text { protein identified } \\
\qquad\left(M_{\mathrm{r}} / \mathrm{p} /\right)^{a}\end{array}$ & sources & $\begin{array}{l}\text { sequence } \\
\text { coverage } \\
(\%)\end{array}$ & $\begin{array}{l}\text { accession } \\
\text { no. }{ }^{b}\end{array}$ & $\begin{array}{l}\text { MOWSE } \\
\text { score }\end{array}$ & $\begin{array}{c}\text { fold } \\
\text { change }^{c}\end{array}$ & $\begin{array}{c}\text { type of } \\
\text { analysis }^{d}\end{array}$ & database & $\begin{array}{c}\text { peptide } \\
\text { sequence }\end{array}$ \\
\hline S1 & $\begin{array}{l}\text { dihydroorotate } \\
\text { dehydrogenase (DHODH) } \\
(45 \mathrm{kDa} / 5.5)\end{array}$ & $\begin{array}{l}\text { Saccharomyces } \\
\text { paradoxus }\end{array}$ & 20 & Q7Z891 & 24 & $3.2^{*}$ & PMF & SwissPort & QAAAAAASTSVKPIFSRDLNEAK \\
\hline \multirow[t]{2}{*}{ S2 } & $\begin{array}{l}\text { enolase (EN) } \\
\quad(54 \mathrm{kDa} / 5.5)\end{array}$ & $\begin{array}{l}\text { Alternaria } \\
\text { alternate }\end{array}$ & 7 & Q9HDT3 & 220 & $2.2^{*}$ & MS/MS & SwissPort & TSDFQIVGDDLTVTNPIR \\
\hline & & $\begin{array}{c}\text { Davidiella } \\
\text { tassiana }\end{array}$ & 7 & P42040 & 220 & & & & \\
\hline S4 & $\begin{array}{l}\text { endonuclease IV (Endo } \\
\text { IV) }(36 \mathrm{kDa} / 5.5)\end{array}$ & $\begin{array}{l}\text { Escherichia } \\
\text { coli }\end{array}$ & 34 & P12638 & 43 & $-3.2^{*}$ & MS/MS & SwissPort & REWAQPAGAILAPNGQDAELWELIR \\
\hline S5 & $\begin{array}{l}\text { formate } \\
\text { dehydrogenase-like } \\
\text { protein }(32 \mathrm{kDa} / 5.5)\end{array}$ & $\begin{array}{l}\text { Magnaporthe } \\
\text { grisea }\end{array}$ & 20 & gi 58257473 & 45 & -1.5 & MS/MS & $\mathrm{NCBI}$ & AILESYLSGKLDYRPQDLIVHAGDYATK \\
\hline S6 & $\begin{array}{l}\text { dihydroorotate } \\
\text { dehydrogenase electron } \\
\text { transfer subunit (DHODH } \\
\text { subunit) ( } 26 \mathrm{kDa} / 5.5)\end{array}$ & $\begin{array}{c}\text { Methanosarcina } \\
\text { mazei Go1 }\end{array}$ & 33 & gi 21227848 & 55 & 1.5 & MS/MS & SwissPort & NLDVTSYDRIAVCGPEIMMASVFR \\
\hline S8 & $\begin{array}{l}\text { adenylate kinase } \\
\text { cytosolic (AK) (ATP-AMP } \\
\text { transphosphorylase) } \\
(24 \mathrm{kDa} / 5.5)\end{array}$ & $\begin{array}{l}\text { Saccharomyces } \\
\text { cerevisiae }\end{array}$ & 22 & P07170 & 26 & $2.5^{\star}$ & MS/MS & SwissPort & IVNDYGIPHISTGDMFRAAMK \\
\hline S9 & $\begin{array}{l}\text { pyruvate kinase (PK) } \\
(55 \mathrm{kDa} / 5.5)\end{array}$ & $\begin{array}{l}\text { Yarrowia } \\
\text { lipolytica }\end{array}$ & 21 & gi 101735 & 28 & $1.8^{*}$ & PMF & $\mathrm{NCBI}$ & REWAQPAGAILAPNGQDAELWELIR \\
\hline S10 & $\begin{array}{l}\text { peroxisomal } \\
\text { NADP-dependent } \\
\text { isocitrate dehydrogenase } \\
\text { (ICDH) }(48 \mathrm{kDa} / 5.5)\end{array}$ & $\begin{array}{r}\text { Emericella } \\
\text { nidulans }\end{array}$ & 16 & gi 15027827 & 32 & $2.5^{\star}$ & PMF & $\mathrm{NCBI}$ & VKNPVVELDGDEMTR \\
\hline S11 & $\begin{array}{l}\text { glyceraldehyde-3-phosphate } \\
\text { dehydrogenase (GAPDH) } \\
(42 \mathrm{kDa} / 5.5)\end{array}$ & $\begin{array}{l}\text { Schizophyllum } \\
\text { commune }\end{array}$ & 10 & P32638 & 9 & $16^{* *}$ & MS/MS & SwissPort & LTGMSMRVPTSNVSVVDLTAR \\
\hline M1 & $\begin{array}{l}\text { aspartyl-tRNA synthetase } \\
1 \text { (AspRS) }(66 \mathrm{kDa} / 5.5)^{e}\end{array}$ & $\begin{array}{l}\text { Streptococcus } \\
\text { mutans }\end{array}$ & 21 & SYD1_STRMU & 60 & $3.6^{*}$ & PMF & Swissprot & QLVMDFGVAGFATATIEKGQVTGSLK \\
\hline M2 & $\begin{array}{l}\text { purine nucleoside } \\
\text { phosphorylase deoD-type } \\
2 \text { (PNP) }(26 \mathrm{kDa} / 5.3)^{e}\end{array}$ & $\begin{array}{l}\text { Shewanella } \\
\text { oneidensis }\end{array}$ & 24 & DEOD2_SHEON & 47 & $1.7^{\star}$ & PMF & Swissprot & QFGDLCVADSRFELAAEINMGLVCFR \\
\hline
\end{tabular}

${ }^{a}$ Theoretical molecular mass $\left(M_{\mathrm{r}}\right)$ of the matched protein and theoretical $\mathrm{p} /$ of the matched protein in the database. ${ }^{b}$ SwissProt or NCBI accession number. ${ }^{c}$ Fold change of protein expression in each protein spot is to compare each spot mean value (from triplicate values) with the corresponding mean value of the control to show the expression change (Student's $t$ test; ${ }^{*} P<0.05,{ }^{* \star} P<0.01$ ). ${ }^{d}$ Proteins identified by using MALDI-TOF/TOF MS through PMF or MS/MS. ${ }^{e}$ Located in the mitochondria.

1 (AspRS), are highly conserved proteins (20). The categories of identified proteins included lyases, oxidoreductases, transferases, and transcriptional repressor. Their metabolisms are involved in glycolysis, TCA cycle, energy generation, protein folding, and peptide biosynthesis. In this work, the enriched mitochondrial protein preparation method for M. pilosus BCRC 31527 was taken from the method used for mitochondrial enrichment from Trichoderma harzianum (12). However, of the five identified proteins extracted from the enriched mitochondrial preparation, three were known to be located in the mitochondria; unexpectedly, two were cytoplasmic contaminants (Table 1). It appears that some modifications are necessary to further minimize the amount of cytoplasmic contaminants, such as an extra wash of the enriched mitochondrial pellet.

Proteome Response to Limitation of Rice Starch in Medium. To evaluate the proteome changes that occurred in the Monascus cultivation during RSF limitation, a comparison of the identified proteins was done between the treated and the control samples. In this work, a total of 16 proteins were identified. The expressions of 12 identified proteins were detected with statistically significant differences $(P<0.05$ or
$P<0.01)$ in the treated culture, among which 10 proteins were up-regulated and only two proteins were down-regulated (Table 1). Expression levels of four identified proteins contained no statistical difference $(P \geq 0.05)$ between the treated culture and the control. The proteins with significantly altered expressions were distributed throughout the entire protein gel. In the treated sample, expression levels of the glycolytic enzymes, glyceraldehyde-3-phosphate dehydrogenase (GAPDH), enolase (EN), and pyruvate kinase (PK), were up-regulated by 16-, 2.2-, and 1.8-fold, respectively, as compared to the corresponding values in the control. Several metabolic enzymes, such as aldehyde dehydrogenase (ALDH), AK, dihydroorotate dehydrogenase (DHODH), and peroxisomal NADP-dependent isocitrate dehydrogenase (ICDH), involved in synthesizing reducing equivalents such as $\mathrm{NAD}(\mathrm{P}) \mathrm{H}$ and ATP, were also up-regulated in the treated sample.

\section{DISCUSSION}

The study showed that, in the treated group after the log phase, the growth of Monascus cultured mycelia was sensitive 
to RSF limitation during cultivation and dropped to half of the corresponding values of the control (Figure 1). Simultaneously, in the treated culture, MBM formation was completely inhibited. However, as compared to current industrial red mold rice production, the major difference in our proteomic analysis was our use of aerobic submerged fermentation rather than aerobic solid-state fermentation commonly used in commercial application (21). Our reason for choosing submerged fermentation is that the cultured cell proteins for 2-DE gel analysis can be specifically harvested apart from the substrate's contamination at the given time. The metabolic significance of the observed altered expression patterns was analyzed as follows.

Three glycolytic enzymes, including GAPDH, EN, and PK, as well as ICDH and AK, were up-regulated in the cells of the treated sample. In glycolysis, GAPDH, regarded as a housekeeping protein involved in basic cell metabolism, has previously been reported to have almost absolute control over the glycolytic flux in S. cerevisiae $(22,23)$. Moreover, PK is a key allosteric regulatory enzyme of the glycolytic pathway, catalyzing the conversion of phosphoenolpyruvate to pyruvate with concomitant phosphorylation of $\operatorname{ADP}$ to $\operatorname{ATP}(24,25)$. The reaction is irreversible under physiological conditions and has long been considered to be critical for the regulation of metabolic flux in the last step of glycolysis (24). In the treated sample, the carbon source level remained almost unused during fermentation (Figure 1A). On the basis of the fact that the carbon source uptake in the cells of the treated culture was near zero, the cultured Monascus cells were presumed to be in a carbon starvation condition. In literature, AK is involved in energy charge equilibrium in a coupling cycle reaction with PK (26). The co-up-regulation of these glycolytic enzymes with AK suggested an increase of glycolytic flux in response to carbon starvation, acting through allosteric regulation by the glycolytic products. In carbon utilization in S. cerevisiae, there are two major strategies for ATP generation from glucose. Glucose utilization through the TCA cycle and respiration proceeds at a low rate with a high yield of ATP, whereas alcoholic fermentation operates at a higher rate but with lower ATP production $(27,28)$. S. cerevisiae is capable of anaerobic fermentation, and when a carbon source is abundant, it preferentially carries out fermentation and represses the TCA cycle/respiration to a relatively low level. Because Monascus is an obligate aerobe, the strategy for regulating flux through fermentation vs the TCA cycle may differ from $S$. cerevisiae. In metabolism, pyruvate is a key glycolytic product occupying a branch point for fermentation, gluconeogenesis, and the TCA cycle (24). In this work, because the carbon source became limiting by using nonfermentable lactose in the treated sample, the potential co-upregulation of $\mathrm{PK}$ and $\mathrm{ICDH}$ together may indicate a metabolic flux shift of pyruvate from glycolysis to the TCA cycle (Figure 3). In aerobic cultivation during the early stationary phase, this pathway may allow more ATP generation through oxidative phosphorylation of the glycolytic products to adapt to carbon starvation requirements in the cellular energy.

In aerobic cultivation of $S$. cerevisiae, carbon starvation is better tolerated than nitrogen starvation under an otherwise complete medium (29). The lack of tolerance for nitrogen starvation in aerobically grown $S$. cerevisiae cells may result from degradation of the carbon source uptake system in cells starved for nitrogen in the presence of a fermentable carbon source (30). Considering the composition of rice contains starch, proteins, and lipids, it is therefore suggested that the destarched fraction could include proteins, lipids, and limited starch (contaminant). In aerobic cultivation of $S$. cerevisiae, lipids,

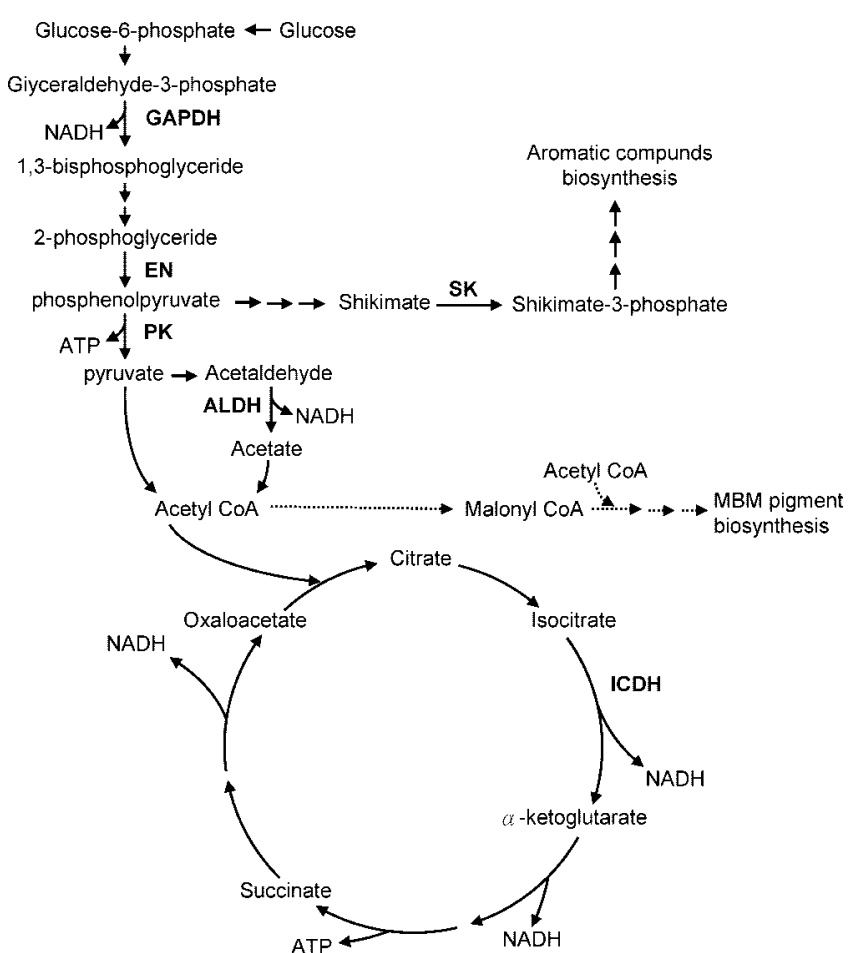

Figure 3. Metabolic pathways of M. pilosus BCRC 31527 under rice starch-limited cultivation. The abbreviations of the metabolic enzymes are as in the Abbreviations section. A bold arrow indicates an increased flux, and a dotted arrow indicates an inhibited flux.

proteins, and amino acids are all potential substrates, entering the glycolytic pathway, $\beta$-oxidation pathway, and TCA cycle for catabolic energy generation (31). In this work, in the treated cultured mycelia under RSF limitation, when the carbon source was exhausted, the cells underwent a "diauxic shift" in which they switched to a full respiratory metabolism, catabolizing amino acids and lipid compounds via the glycolytic pathway, $\beta$-oxidation pathway, TCA cycle, and oxidative phosphorylation for generating ATP.

In addition, it followed from the above condition that, in the treated sample, the major glycolytic flux of the cultured filamentous cells required that acetyl-CoA entered the activated TCA cycle for providing enough TCA cycle intermediates for ATP generation (Figure 3). On the other hand, the MBM formation pathway is involved in using acetyl-CoA as a building block in the TCA cycle branch $(5,32,33)$. From the resulting data, MBM production was completely inhibited in the treated sample. In the cultured filamentous cells of the treated medium during early stationary phase, after exhaustion of most of the TCA cycle intermediates in oxidative phosphorylation, switching to the polyketide branch pathway may be repressed because it required production of extra intermediates to transition into the branch pathway.

Another interesting observation was the co-up-regulation of the three metabolic enzymes, purine nucleoside phosphorylase (PNP), ALDH, and DHODH, together with ICDH. DHODH is involved in dihydroorotate reduction, which provides sufficient pyrimidine nucleotide pools and $\mathrm{NAD}(\mathrm{P}) \mathrm{H}$ for cell metabolism (34). In fermentation of $S$. cerevisiae, when the carbon pool is depleted, it is a crucial requirement that DHODH converts dihydroorotate to orotate independently of the respiratory chain (35). Furthermore, PNP functions in the salvage pathway, enabling cells to utilize purine bases recovered from metabolized purine ribonucleosides to synthesize purine nucleotides (36). In addition, ICDH, which catalyzes the oxidative decarboxyl- 
ation of isocitrate to form 2-oxoglutarate, coupled to production of $\mathrm{NAD}(\mathrm{P}) \mathrm{H}$, is an essential and rate-limiting step in the TCA cycle (37). This reaction, as an important branch point between catabolic and anabolic processes in cells, controls the TCA cycle carbon flow through the allosteric effectors NAD(P)H and ATP (38). In the treated sample, the cultured Monascus cells were subjected to a nonfermentable carbon source, with poor cell growth and MBM production completely inhibited. Because it is known that stationary-phase cells often have a higher tolerance to stress than cells in the other physiological states (39), the resulting increased expression of these enzymes was required to face carbon source depletion and thus manage adaptation to a starvation condition. It would increase the anabolism flux through TCA cycle or salvage pathway, which in turn leads to ATP generation or an increase in nucleotide pools for the superior starvation tolerance of stationary-phase survival during fermentation.

In parallel, shikimate kinase (SK) and AspRS were co-upregulated in the treated sample. SK, which catalyzes the phosphoryl transfer from ATP to shikimic acid, is involved in the shikimate pathway, responsible for the biosynthesis of aromatic amino acids and related aromatic compounds (Figure 3), such as chorismate and ubiquinone, in fungi, yeasts, and bacteria (40). Interestingly, ubiquinone, as an essential electron carrier, accepts electrons in the respiratory electron transport chain into oxidative phosphorylation for ATP generation (41). The up-regulated SK may be a reflection of increased metabolic shift in the shikimate pathway for the biosynthesis of related aromatic compounds, such as ubiquinone, in response to energy starvation in the treated group cells. Even more interesting, aminoacyl-tRNA synthetases (aaRSs) play a critical role in protein synthesis, since they are responsible for the accurate charging of a given set of tRNAs with their cognate amino acids (42). AaRSs have been reported to be implicated, at least indirectly, in the regulation by certain amino acid biosynthetic pathways in a feedback mechanism (43). In eukaryotes, feedback regulation acts at the level of mRNA ${ }^{\text {aaRs }}$ accumulation and requires the presence of specific domains in the mRNA that are recognized by the encoded protein (44). Because mRNAs can be targeted in different subcellular compartments corresponding to the different stages of their functional lifecycle, protein binding to mRNA can inhibit transcription or translation of the mRNA in the nucleus, in the cytoplasm, or in the mitochondria (44). S. cerevisiae AspRS is the first example of a eukaryal aminoacyl-tRNA synthetase regulated via a feedback mechanism $(44,45)$. In contrast to the general shut-down of translation upon starvation, a few genes, such as $g d h l$ (glutamate dehydrogenase) and gltl(glutamate synthase), are up-regulated in the carbon-starved stationary phase in S. cerevisiae under the presence of a good nitrogen source (28). In this work, these two genes, SK located in the cytoplasm and AspRS located in the mitochondria, were induced under carbon limitation in the treated samples, suggesting that there was cross-talk between carbon and nitrogen metabolism, probably through some key regulators controlling both.

Interestingly, by comparison, the up-regulation in endonuclease IV (Endo IV) and glycoprotein endopeptidase occurred in the control. Endo IV is known to have apurinic/apyrimidinic lyase activity (46). In $S$. cerevisiae, Endo IV is involved in DNA repair mechanisms to maintain cell viability and genomic stability (47). Glycoprotein endopeptidase, a chaperone protein, is involved in folding proteins to acquire biological function (48). It is suggested that the increased induction of these two enzymes in the control may be related to the enhanced cell growth and maintenance during the early stationary phase.

This work showed that the metabolic regulation of $M$. pilosus BCRC 31527 cells was sensitive to limitation of RSF during cultivation, exhibiting a decrease in cell growth and complete suppression of MBM formation. Our proteomic comparison of the cultured mycelia revealed that RSF limitation induced an obviously altered expression pattern of M. pilosus BCRC 31527 proteins. Taken together, the proteins with deregulated expression were involved in glycolysis, TCA cycle, energy generation, protein folding, and peptide biosynthesis. The observed deregulation suggested that, in the treated sample, the necessary energyrequiring adaptations for early stationary phase survival are executed for the cultured Monascus cells to withstand carbon depletion, including the induction of salvage pathways. These different protein expression profiles may reflect changes in posttranslational regulation of enzyme activity in the cells during RSF limitation. The results of this work in Monascus offer clues for understanding the mechanism that leads to an alteration in protein synthesis for adaptation under rice starch limitation during cultivation and may facilitate the assessment of a possible role for these proteins in the industrial fermentation process of this fungus. Understanding the biochemical events involved in limitation of rice constituents in Monascus cultivation will have practical applications for the improvement of the industrial production of secondary metabolites of the fungus.

\section{ABBREVIATIONS USED}

ACN, acetonitrile; AK, cytosolic adenylate kinase; ALDH, aldehyde dehydrogenase; AspRS, aspartyl-tRNA synthetase 1; CHAPS, 3-[(3-cholamidopropyl) dimethylammonio]-1-propane sulfonate; CHCA, $\alpha$-cyano-4-hydroxycinnamic acid; DHODH, dihydroorotate dehydrogenase; DTT, dithiothreitol; EN, enolase; Endo IV, endonuclease IV; GAPDH, glyceraldehyde-3-phosphate dehydrogenase; IAA, iodoacetamide; ICDH, peroxisomal NADP-dependent isocitrate dehydrogenase; HEPES-KOH, N-(2Hydroxyethyl) piperazine- $\mathrm{N}^{\prime}$-(2-ethanesulfonic acid) potassium salt; MBM, monascorubramine; RSF, rice-starch fraction; SDS, sodium dodecyl sulfate; SK, shikimate kinase; PK, pyruvate kinase; PMSF, phenylmethanesulfonyl fluoride; PNP, purine nucleoside phosphorylase; TFA, trifluoroacetic acid.

\section{ACKNOWLEDGMENT}

We gratefully thank Cheng-Chung Liao Ph.D. from The Institute of Biochemistry, National Yang Ming University, for technical assistance with MALDI-TOF/TOF MS.

\section{LITERATURE CITED}

(1) Ma, J.; Li, Y.; Ye, Q.; Li, J.; Hua, Y.; Ju, D.; Zhang, D.; Cooper, R.; Chang, M. Constituents of red yeast rice, a traditional Chinese food and medicine. J. Agric. Food Chem. 2000, 48, 5220-5225.

(2) Endo, A.; Hasumi, K. Biochemical aspect of HMG CoA reductase inhibitors. Adv. Enzyme Regul. 1989, 28, 53-64.

(3) Endo, A.; Monacolin, K. A new hypocholesterolemic agent that specifically inhibits 3-hydroxy-3-methylglutaryl coenzyme A reductase. J. Antibiot. (Tokyo) 1980, 33, 334-336.

(4) Hajjaj, H.; Blanc, P. J.; Groussac, E.; Goma, G.; Uribelarrea, J. L.; Loubiere, P. Improvement of red pigment/citrinin production ratio as a function of environmental conditions by Monascus ruber. Biotechnol. Bioeng. 1999, 64, 497-501.

(5) Hajjaj, H.; Klaebe, A.; Loret, M. O.; Tzedakis, T.; Goma, G.; Blanc, P. J. Production and identification of N-glucosylrubropunctamine and $\mathrm{N}$-glucosylmonascorubramine from Monascus ruber and occurrence of electron donor-acceptor complexes in 
these red pigments. Appl. Environ. Microbiol. 1997, 63, 26712678.

(6) Kennedy, J.; Auclair, K.; Kendrew, S. G.; Park, C.; Vederas, J. C.; Hutchinson, C. R. Modulation of polyketide synthase activity by accessory proteins during lovastatin biosynthesis. Science $\mathbf{1 9 9 9}$ 284, 1368-1372.

(7) Wang, J. J.; Lee, C. L.; Pan, T. M. Modified mutation method for screening low citrinin-producing strains of Monascus purpureus on rice culture. J. Agric. Food Chem. 2004, 52, 69776982.

(8) Hajjaj, H.; Niederberger, P.; Duboc, P. Lovastatin biosynthesis by Aspergillus terreus in a chemically defined medium. Appl. Environ. Microbiol. 2001, 67, 2596-2602.

(9) Teng, S. S.; Feldheim, W. Anka and anka pigment production. J. Ind. Microbiol. Biotechnol. 2001, 26, 280-282.

(10) Kolkman, A.; Olsthoorn, M. M.; Heeremans, C. E.; Heck, A. J.; Slijper, M. Comparative proteome analysis of Saccharomyces cerevisiae grown in chemostat cultures limited for glucose or ethanol. Mol. Cell. Proteomics 2005, 4, 1-11.

(11) Hecker, M.; Volker, U. Towards a comprehensive understanding of Bacillus subtilis cell physiology by physiological proteomics. Proteomics 2004, 4, 3727-3750.

(12) Grinyer, J.; McKay, M.; Herbert, B.; Nevalainen, H. Fungal proteomics: Mapping the mitochondrial proteins of a Trichoderma harzianum strain applied for biological control. Curr. Genet. 2004, $45,170-175$.

(13) Lin, W. Y.; Ting, Y. C.; Pan, T. M. Proteomic response to intracellular proteins of Monascus pilosus grown under phosphatelimited complex medium with different growth rates and pigment production. J. Agric. Food Chem. 2007, 55, 467-474.

(14) Patindol, J.; Wang, Y. J. Fine structures and physicochemical properties of starches from chalky and translucent rice kernels. $J$. Agric. Food Chem. 2003, 51, 2777-2784.

(15) Lin, W. Y.; Chang, J. Y.; Tsai, P. C.; Pan, T. M. Metabolic protein patterns and monascorubrin production revealed through proteomic approach for Monascus pilosus treated with cycloheximide. $J$. Agric. Food Chem. 2007, 55, 5559-5568.

(16) Lin, W. Y.; Song, C. Y.; Pan, T. M. Proteomic analysis of Caco-2 cells treated with monacolin K. J. Agric. Food Chem. 2006, 54, 6192-6200.

(17) Teng, S. S.; Feldheim, W. The fermentation of rice for anka pigment production. J. Ind. Microbiol. Biotechnol. 2000, 25, 141146.

(18) Cordwell, S. J.; Wilkins, M. R.; Cerpa-Poljak, A.; Gooley, A. A.; Duncan, M.; Williams, K. L.; Humphery-Smith, I. Cross-species identification of proteins separated by two-dimensional gel electrophoresis using matrix-assisted laser desorption ionisation/timeof-flight mass spectrometry and amino acid composition. Electrophoresis 1995, 16, 438-443.

(19) Wilkins, M. R.; Williams, K. L. Cross-species protein identification using amino acid composition, peptide mass fingerprinting, isoelectric point and molecular mass: A theoretical evaluation. $J$. Theor. Biol. 1997, 186, 7-15.

(20) Faulhammer, F.; Konrad, G.; Brankatschk, B.; Tahirovic, S.; Knodler, A.; Mayinger, P. Cell growth-dependent coordination of lipid signaling and glycosylation is mediated by interactions between Sac1p and Dpm1p. J. Cell Biol. 2005, 168, 185-191.

(21) Chiu, C. H.; Ni, K. H.; Guu, Y. K.; Pan, T. M. Production of red mold rice using a modified Nagata type koji maker. Appl. Microbiol. Biotechnol. 2006, 73, 297-304.

(22) Sanchez, N. S.; Calahorra, M.; Gonzalez-Hernandez, J. C.; Pena, A. Glycolytic sequence and respiration of Debaryomyces hansenii as compared to Saccharomyces cerevisiae. Yeast 2006, 23, 361374.

(23) Rosenblitt, A.; Agosin, E.; Delgado, J.; Perez-Correa, R. Solid substrate fermentation of Monascus purpureus: Growth, carbon balance, and consistency analysis. Biotechnol. Prog. 2000, 16, $152-162$

(24) Pearce, A. K.; Crimmins, K.; Groussac, E.; Hewlins, M. J.; Dickinson, J. R.; Francois, J.; Booth, I. R.; Brown, A. J. Pyruvate kinase (Pyk1) levels influence both the rate and direction of carbon flux in yeast under fermentative conditions. Microbiology 2001 , 147, 391-401.

(25) Bond, C. J.; Jurica, M. S.; Mesecar, A.; Stoddard, B. L. Determinants of allosteric activation of yeast pyruvate kinase and identification of novel effectors using computational screening. Biochemistry 2000, 39, 15333-15343.

(26) Coevoet, M. A.; Hervagault, J. F. Irreversible metabolic transitions: the glucose 6-phosphate metabolism in yeast cell-free extracts. Biochem. Biophys. Res. Commun. 1997, 234, 162-166.

(27) Brauer, M. J.; Saldanha, A. J.; Dolinski, K.; Botstein, D. Homeostatic adjustment and metabolic remodeling in glucoselimited yeast cultures. Mol. Biol. Cell 2005, 16, 2503-2517.

(28) Wu, J.; Zhang, N.; Hayes, A.; Panoutsopoulou, K.; Oliver, S. G. Global analysis of nutrient control of gene expression in Saccharomyces cerevisiae during growth and starvation. Proc. Natl. Acad. Sci. U.S.A. 2004, 101, 3148-3153.

(29) Nilsson, A.; Pahlman, I. L.; Jovall, P. A.; Blomberg, A.; Larsson, C.; Gustafsson, L. The catabolic capacity of Saccharomyces cerevisiae is preserved to a higher extent during carbon compared to nitrogen starvation. Yeast 2001, 18, 1371-1381.

(30) Busturia, A.; Lagunas, R. Catabolite inactivation of the glucose transport system in Saccharomyces cerevisiae. J. Gen. Microbiol. 1986, 132, 379-385.

(31) Thomsson, E.; Gustafsson, L.; Larsson, C. Starvation response of Saccharomyces cerevisiae grown in anaerobic nitrogen- or carbon-limited chemostat cultures. Appl. Environ. Microbiol. 2005, 71, 3007-3013.

(32) Hajjaj, H.; Klaebe, A.; Goma, G.; Blanc, P. J.; Barbier, E.; Francois, J. Medium-chain fatty acids affect citrinin production in the filamentous fungus Monascus ruber. Appl. Environ. Microbiol. 2000, 66, 1120-1125.

(33) Hajjaj, H.; Klaebe, A.; Loret, M. O.; Goma, G.; Blanc, P. J.; Francois, J. Biosynthetic pathway of citrinin in the filamentous fungus Monascus ruber as revealed by $13 \mathrm{C}$ nuclear magnetic resonance. Appl. Environ. Microbiol. 1999, 65, 311-314.

(34) Zameitat, E.; Knecht, W.; Piskur, J.; Loffler, M. Two different dihydroorotate dehydrogenases from yeast Saccharomyces kluyveri. FEBS Lett. 2004, 568, 129-134.

(35) Nagy, M.; Lacroute, F.; Thomas, D. Divergent evolution of pyrimidine biosynthesis between anaerobic and aerobic yeasts. Proc. Natl. Acad. Sci. U.S.A. 1992, 89, 8966-8970.

(36) Pereira, D. G.; Kilikian, B. V. Effect of yeast extract on growth kinetics of Monascus purpureus. Appl. Biochem. Biotechnol. 2001, 91-93, 311-316.

(37) Barnes, L. D.; McGuire, J. J.; Atkinson, D. E. Yeast diphosphopyridine nucleotide specific isocitrate dehydrogenase. Regulation of activity and unidirectional catalysis. Biochemistry 1972, 11, $4322-4329$.

(38) Zhao, W. N.; McAlister-Henn, L. Assembly and function of a cytosolic form of NADH-specific isocitrate dehydrogenase in yeast. J. Biol. Chem. 1996, 271, 10347-10352.

(39) Steels, E. L.; Learmonth, R. P.; Watson, K. Stress tolerance and membrane lipid unsaturation in Saccharomyces cerevisiae grown aerobically or anaerobically. Microbiology 1994, 140, 569-576.

(40) Graham, L. D.; Gillies, F. M.; Coggins, J. R. Over-expression of the yeast multifunctional arom protein. Biochim. Biophys. Acta 1993, 1216, 417-424.

(41) Oyedotun, K. S.; Lemire, B. D. The quinone-binding sites of the Saccharomyces cerevisiae succinate-ubiquinone oxidoreductase. J. Biol. Chem. 2001, 276, 16936-16943.

(42) Burke, D. J.; Church, D. Protein synthesis requirements for nuclear division, cytokinesis, and cell separation in Saccharomyces cerevisiae. Mol. Cell. Biol. 1991, 11, 3691-3698.

(43) Grundy, F. J.; Henkin, T. M. Conservation of a transcription antitermination mechanism in aminoacyl-tRNA synthetase and amino acid biosynthesis genes in gram-positive bacteria. J. Mol. Biol. 1994, 235, 798-804.

(44) Ryckelynck, M.; Masquida, B.; Giege, R.; Frugier, M. An intricate RNA structure with two tRNA-derived motifs directs complex formation between yeast aspartyl-tRNA synthetase and its mRNA. J. Mol. Biol. 2005, 354, 614-629. 
(45) Frugier, M.; Ryckelynck, M.; Giege, R. tRNA-balanced expression of a eukaryal aminoacyl-tRNA synthetase by an mRNA-mediated pathway. EMBO Rep. 2005, 6, 860-865.

(46) Ramotar, D.; Demple, B. Functional expression of Escherichia coli endonuclease IV in apurinic endonuclease-deficient yeast. J. Biol. Chem. 1996, 271, 7368-7374.

(47) Wilson, W. A.; Wang, Z.; Roach, P. J. Regulation of yeast glycogen phosphorylase by the cyclin-dependent protein kinase Pho85p. Biochem. Biophys. Res. Commun. 2005, 329, 161-167.
(48) Plemper, R. K.; Egner, R.; Kuchler, K.; Wolf, D. H. Endoplasmic reticulum degradation of a mutated ATP-binding cassette transporter Pdr5 proceeds in a concerted action of Sec61 and the proteasome. J. Biol. Chem. 1998, 273, 32848-32856.

Received for review April 17, 2007. Revised manuscript received July 5, 2007. Accepted July 6, 2007.

JF071109U 